\title{
DEVELOPMENT OF HUMAN RESOURCES IN COMMERCIAL BANKS NEED FOR A NEW APPROACH
}

\author{
* Mr. Mahesh Deshpande
}

\begin{abstract}
The highly competitive banking scenario calls for higher skill and quality of human resources for giving a competitive edge, for this banks need to take organization wide transformational initiative. Performance of the banks in our country is inextricably linked with attitude, training, achievement motivation and thoughts of the employees.

Far reaching reforms have been set in motion and implemented in the area of technology, financial and prudential norms, but reforms in the area of human resources have been lagging behind and halting, commercial banks were not having an independent HR policy, their recruitment, training, promotion, deployment of the staff aie characterized by high level of rigidities, performance appraisal was of a routine type.

There is a need for the banks to give proper attention to some critical issues viz, 1. Designing policies for HRD 2. Defining the role of the Board and CEO 3. Improving the productivity of the employees 4. Institutionalization and implementation of performance measurement and Management system 5.Development of leaders for critical roles 6. Compensation, Motivation and Reward mechanism 7. Development of Competency based strategic HR systems 8 . Implementation of HRM systems 9 . Knowledge management initiatives for learning and growth 10. Skill development, Attitudinal Reorientation and Managing diversities.

The other issues discussed in this paper are, Measures for organizational renewal, Career management system, Training and development agenda etc..,

\section{Introduction:}

Banking sector in India has witnessed a paradigm shift in the post economic reform period. It has become strong, stable and vibrant with a dominating share in gross financial assets. Banking sector has continued to be the principal purveyor of finance and its all-pervasive intermediation has not been challenged by other financial entities. It has become more entrenched and diversified having made forays into insurance and investment banking. Banks have become tech-savvy and competitive as well.

They are profitable and stable with impressive performance indices.

Indian banks represent a massive structure with over 65,000 branches 19 government banks, 21 old private sector banks and 9 new private sector banks in addition to 36 foreign banks. The market share in terms of total assets of public sector banks was reduced from $90 \%$ in 1991 to $75.7 \%$ in 2003 , with the advent of new private sector banks, which accounted for $11.3 \%$ of assets while old private sector banks accounted for $6.3 \%$. Foreign banks

* The author is faculty member in Global educare foundation's BBA College Hubli, and the Research student working under the guidance of Dr.H.Y.Kamble, Professor Dept of Studies and Research in Commerce. Karnataka University, Dharwad.
\end{abstract}


have not significantly enlarged their market share during this period having improved only to $6.8 \%$ in 2003 from $6.3 \%$ in 1991 .

The aggregate deposit of commercial banks stood at $\mathrm{Rs} .13,55,880$ crore registering a growth rate of $14 \%$ over the year 2002. Loans and advances of the banking sector accounted to Rs.7, 40,473 crores registering increase by $14.73 \%$ over the previous year 2002. Net profit rose to Rs.5, 501 crore from Rs. 5,173 crore for the year $2002-$ a rise by $6.3 \%$. Investments stood at Rs.6, 93,791 crore- a rise by $18.14 \%$ over the year 2002, Indian Banks provide finance to the industries, trade, retail sector, agriculture and small-scale sector. The banks have a strong presence in rural and semi urban areas too.

\section{Developing Human Resource in Banks - \\ An Imperative in the Competitive \\ Environment:}

The emerging banking scenario is highly competitive posing challenges in three critical quartersTechnological, operational and on the human resources front. For an effective meeting of these multiple challenges banks need to take organization wide transformation in initiative so that they acquire the desired competence to gain substantial financial strength and also the necessary size and skill to compete with the global fraternity (Anil K.Khandelwal-2005).

In the era of high technology it is the quality and the skills of human capital that will give a competitive advantage to a business organization. Successful organizations will be those which skillfully and imaginatively align and organically integrate their human resource and technology policies in order to get best value from both and leverage them for enhanced business performance.

The performance of banks in our country in the new developmental and catalyzed role is inextricably linked with the attitudes, training and achievements, motivation and imagination of their employees. A continuous overhaul of the human machinery by an integrated, conscious, long-term strategy of effective manpower planning and human resource development through training can ensure a speedy and sensitive translation of social goals into sound banking.

Developing competencies and personality of staff members to meet the organizational needs arising out of technical, legislative and knowledge in the fast changing banking scenario should be made a continuous process. The Working Group on RRB, headed by M.S.Chalapati Rao has observed that the arrangements for training and development of the staff of RRB's are not adequate and suggested that there is an intense need for coordination in the efforts of these institutions particularly in regard to the training need and analysis, training strategies and methodologies, trainers training development of training material cost and funding of training programmes and mutual sharing of training to the RRB's while enhancing efficiency of the training programmes being conducted by them (Dinkar Rao2006).

\section{Competition and Skill Formation of Human Resource:}

Financial systems that are bank based such as in Germany and Japan employers can internalize the strategy of managing human resource via job ladders and screening where as in market based systems such as in the UK and US an external strategy where recruiting, laying off occurs as demand changes and market signals help set wages. India is bank based system such that in the organized sector till recently followed the internal strategy of managing are liberalized and firms face increased competition the ability to pass on the costs of workers privileges such as job security diminishes depending on the state of markets. The new epoch of competition thus calls for job enlargement and 
multi skilling and in some cases rearranging employees rather than recomposing the tasks they perform (Errol D'Souza-2003).

\section{Economic Reforms and Reforms in HR Policies:}

Banking industry has undergone tremendous change over the past couple of decades in various countries. The reforms process in India in financial sector embraced many components- financial asset quality, prudential norms, technology, opening of private sector banks and private banks and human resources. While far reaching reforms have been set in motion and largely implemented in areas financial and prudential norms and to an extent in the area of technology reforms in the area of human resources have been lagging behind and halting. Keltner and Finegold (1996) found that banks typically have not made the necessary investments in the human resources to improve customer service and relationships instead they turn their attention to cutting labour costs and competing on price. The authors have suggested that banks can increase skill levels and reduce turnover by creating a new employment contract that emphases competence based carrier ladders for entry level employees, modular training for high skill positions and higher levels of internal recruitment.

Traditional HR functions of banks focused on establishment and administrative roles subsequently industrial relations (IR) came to occupy a central place in the HR domain issues in HR were largely dictated and driven by the agenda of the unions which were essentially in the nature of demands. Bank managements often shield away from raising issues of substance relevant to HR reforms. Banks followed a policy of buying peace than strategically leveraging industrial relations for business and productivity improvements.

\section{Need for Appropriate Policies for Human Resource Development:}

The commercial banks particularly Public Sector Banks which dominates the banking sector in the country were not having an independent HR Policy and hence they could not recruit and induct young talent to tune with the emerging requirements. Their training system continued to be nebulous and did not develop the right mix of skills and competencies. Promotions under the standardized regulations have resulted in several inconsistencies in various cadres. In the matter of development of staff the banks continued to be governed by industry and bank level settlements resulting in high rigidity in their ability to deploy them as per need. In the area of performance appraisal of officers they have been following a common one fit for all formats, which does not take care of individual organizational needs. Hence they have to compete with others with inadequate and inappropriate HR Policies and systems.

Banks have paid little attention to more critical issues like staff training and development relevant to the new era, management development and succession, leadership development, acquisition and honoring of new skills and competencies, performance measurement and management and the like. The very HR systems and subsystems did not keep pace with the emerging requirements of competitive market place.

\section{Narasimhan Committee on Human Resource Development}

The committee on financial sector reforms known as the Narasimhan Committee constituted by the government to recommend fundamental reform measures in banking and financial sector had strongly argued in its first report in 1991 for reaching reforms in the area of organization and methods, systems improvement and issues related to human resources-along with reforms in the operational 
areas. Further the second Narasimhan Committee report ((1998) emphasized the necessity on parallel reforms in HR. However the recommendations have not been implemented largely. There is need for embracing and enthusiastically implement worldclass HR practices four banks have to become worldclass financial institutions, with India emerging as a dominant knowledge power it is in the fitness of things that Indian commercial banks accord high value to human capital and take momentous steps forward to reach world class HR capital adequacy.

\section{Designing Policies for Human Resource Development by Banks:}

Human Resource Development (HRD) is a multidimensional concept. HRD is growing fast as an important management function in the modern large sized organizations (Ajaykumar Singh 1997). HRD as a value system treats human as a resources which is instrumental in attaining organizational goal. Human Resource Development (HRD) is essentially an integral part of HRM. Its major focus is an extracting extra ordinary performance from an ordinary employee by enhancing his/her physical, mental, social and spiritual well being and enabling that individual to derive maximum level of life satisfaction (P.SYadapadithaya 1998). The following objectives of synchronizing the modern business organization with the interests of human resources have been aptly mentioned by the author.

- Corporate goals must factor in individual career growth.

- Company profits must be linked to personal rewards.

- Organizational learning must involve employee training and development.

- Job responsibilities must facilitate personal development.

- Business strategies must consider human resource issues.

\section{Designing HR Policies in Banks:}

Given the enormity of issues involved in the human resources development in banks a number of initiatives are required at bank level. The following measures will help in designing HR policies in banks.

\section{- Role of the Board and CEO:}

In view of the criticality of HR issues the banks now need to spend quality time on formulation and deliberation of HR strategy, involving leadership development, succession planning for critical levels such as GMs/DGM's/business heads territorial heads etc, performance standards, redesign of organizational structure compensation and rewards management and other initiatives needed to create a proper organizational climate. The CEO's main task would be ensure capability building and use it as a differentiator for gaining competitive strength to his/her organization.

\section{- Improvements in Employee Productivity :}

Improvements in productivity standards could be brought about by massive skill up gradation creating digital competencies to handle operational challenges of core banking, rationalization of manpower mix at branches, role redefinition etc.

- Institutionalization and Implementation of

Performance Measurement and Management System:

Reforming the performance appraisal system by making it more objective and linked to corporate business objectives needs to be addressed by banks key performance indicators need to be scientifically assured and objectively linked with organizational goals so that the performance of the employees can be assessed on critical parameters. There is need to bring all levels of employees within the purview of performance measurement. 
Commercial banks need to institutionalize new performance measured systems like balance scorecards, activity based costing etc, which could provide real linkage between key performance variables and individual efforts so that a realistic organized and predictable pattern is available for performance analysis and review.

\section{- Development of Leaders for Critical Roles :}

Banking system requires leadership at three cultural levels i.e. strategic leaders (corporate level), operational leaders (regional and zonal level) and tactical leaders (branch managers). Banks should evolve a proper system of identification of employees having strong leadership potential to lead people in teams at these ievels and can deliver as per expectations. These people need to be groomed through diverse role exposures, customized training and development inputs and also through planned career progression systems. Banks need to focus on ingenuous methods to create a pool of leaders who have strong and wide vision, are quick yet effective thinkers and sound decision makers and have strong relationship skills. The process of leadership program is continuous one and banks should institutionalize it.

\section{- Compensation, Motivation and Reward Mechanism :}

There is need for evolving such compensation standards that can provide a linkage between risk and reward performance and payment. The Narasimhan Committee Reports I and II have stressed the need for graduating from the industry level wage settlement to individual bank level settlement in the matter of compensation and reward. Under the autonomy measures banks can provide differential pay packages to recognize special skills and high performance. This would result in greater motivation for high achievers and inducement to those who are not performing but need to perform. Banks have to device igneous ways to reposition the overall compensation and reward system from currently "hygiene" level to the level of "motivation."

\section{- Development of Competency Based Strategy HR Systems :}

Human Resource Organization (HR) structure should focus on the critical requirements of banks such as:

$\checkmark$ How effective and need based training can be imparted to different business divisions.

$\checkmark$ How requirement and promotion policies can answer specific manpower needs.

$\checkmark$ How compensation and reward systems can be designed to attract and retain the best talent from the market.

$\checkmark$ How talent within the organization can be identified and nurtured for future requirements.

$\checkmark$ How frontline staff can be trained in providing effective customer service.

The answer to the above questions is to be found by redesigning system and policies with competency as the role justification or criterion.

\section{- Implementation of Human Resource Management Systems :}

It is generally expected that, the Commercial banks should have an in depth knowledge about their people, their abilities, their desires, their career profile etc, so that the effective decisions pertaining to the HR can be taken. There is need for streamlining their HR operations and reduce costs so that the productivity of HR can be increased. Human Resource Management Systems (HRMS) can integrate various sub systems of $H R$ and provide a 360 degree view of people and functions. An HRMS platform would also enable the bank to establish a work flow based processing systern and provide employee self service functionalities which would then lead to increased employee involvement 
and motivation. HRMS would bring out transparency in HR governance and cost effective human resource management which adds value to the organization.

\section{- Knowledge Management Initiatives for Learning and Growth :}

Banking sector is a constituent of service sector. It continues to relay heavily upon human capital as a differentiator for providing a competitive advantage. It is necessary to achieve innovation in work and management practices for achieving high standards in product and service delivery at competitive price. This can be brought about only through continuous knowledge enrichment and process improvements with knowledge management.

\section{- Skill Development, Attitudinal}

\section{Reorientation and Managing Diversities :}

There is need for preparing man power deployment and utilization plans in such a way that employees are provided cross functional and cross cultural exposure to develop their sensitivity and ability to cope with issues and resolve them. There is also need for comprehensive training on sales and service skills, communication, attitude and behavioral flexibilities. Apart from front line staff gaps too exist in middle and higher-level employees. Hence, skill enhancement programs would have to be initiated in tune with the organizational requirements. Primarily the gaps are in handling technology and work flow systems analytical abilities, selling skills, risk assessment planning and coordination, customer and market responsiveness etc.

\section{Measures for Organizational Renewal :}

Measures involved in organizational renewal are HR audit, organizational health survey and employee satisfaction survey. They should be undertaken to remove systematic deviations and enhance organizational maturity. There is need for action research for finding solutions to operational issues and for continuous improvements in organizational systems and practices. Innovative employee's involvements programmes need to be undertaken for creating organization wide impact and change. Banks must also focus on enrichment of organizational culture, which is a long and continuous process.

HRD audit in all the vital areas like training, performance management, compensation and benefit administration, recruitment and promotion has a far reaching effect in reducing deviations, plugging revenue leakages and improving system effectiveness.

\section{Career Management Systems :}

Career management systems are essential ingredients for harnessing the true worth of people career planning and career development subsystems are important as effective measures for ensuring employee motivation and commitment. There must be suitable interventions and processes to facilitate employees to choose their career options by way of counseling, development inputs, role exposure and development initiatives etc.

\section{Training and Development Agenda :}

Training should be aligned with the business requirements of the banks. The focus of training must be on changing the attitude of people to become customer centric, on enhancing selling skills, service delivery, bringing cultural alignment and also to transform them into the intrapreneural managers. Preparing a program for creating digital awareness and developing people competencies to operate in technology oriented banking environment is another major issue to be addressed in HRD. Executive education should also become a continuous activity. Banks should collaborate with prestigious Indian and global business schools to impart the desired executive skills. 


\section{REFERENCES}

1. Anil Kumar Singh (2003): Philosophy of Management in Indian Organizations. The Indian Journal of Commerce Vol. $56 \mathrm{Nov}$ 2002 and 3 April-Sep 2003.

2. Anil K Khandelwal (2005): Criticality of HR Reforms for Public Sector Banks. Economic and Political Weekly Vol. XL No. 12 March 2005.

3. Ajay Kumar Singh (1998): HRD Perspectives in the $21^{\text {st }}$ Century-Indian Journal of Commerce Vol-51 No.4 Oct-Dec 1998.

4. Dinkar Rao (2006): Human Resource issues at Regional Rural Banks Economic and Political Weekly-March 18, 2006.

5. Errol D'Souza (2002): Financial Markets, Human Resource Policies and Flexibility: Economic and Political Weekly, Feb 23, 2002.
6. Keltner Band and Finegold (1996): Adding Value in Banking, Human Resource Innovations for Service Firms-Sloan Management Review. Vol 38 No.1.

7. P.S. Yadapadithaya (1998): Strategic Human Resource Development (SHRD)-A Key to Competitive Advantage- Indian Journal of Commerce Vol-51.No.4-OctDec-1998.

8. RBI quarterly hand out: Banking statistics, Basic statistics of scheduled commercial banks in india, March 2002, Vol 32. 